\title{
Science and Honour: The 11th International Geological Congress in Stockholm 1910
}

\author{
1 Scientific Biography Center, Falkvägen 2, SE-75756 Uppsala, Sweden. E-mail: bjorn.sundquist@swipnet.se \\ 2 Department of Historical Studies, Umeå University, SE-90187 Umeå, Sweden. E-mail: christer.nordlund@histstud.umu.se
}

In the late 19th and the early 20th century, with expanding industrialism and urbanisation, the idea of the nation state grew strong in Sweden. In this nationalistic environment, nature and the natural sciences assumed an important unifying role. The search for natural resources and sources of energy inspired political support and research. The exploitation of nature was looked upon as a prerequisite for the modernization of the country, and indeed was to become the basis for Sweden's welfare. It was under these circumstances that, in 1906, the 11th IGC was invited to Stockholm in 1910. A request for a Government grant focused on the international development of science but also stressed the national importance. Sweden had, it was said, its ranking position among nations to defend, to uphold its position among civilized nations, and to maintain its distinguished tradition in the spheres of natural sciences and mining operations.

The main topics of the Congress were iron ore resources, post-glacial climate change, glacial erosion, the Cambrian fauna, geology of the Precambrian, and geology of the polar regions. Three exhibitions and 24 excursions were arranged, and 41 guidebooks printed. The number of members present was 625, from 37 countries and six continents. The final cost for arranging the 11th IGC was SEK 125,000 (approximately $€ 540,000$ today). A novel experience in the tradition of the IGCs was the world-wide inquiries about the resources of iron ore and about climate change. Such thematic, worldwide investigations subsequently came to attract the attention of many IGCs. A proposition to establish a commission for the publication of an international stratigraphic dictionary was approved by the Congress, and a subcommission was set up with commissioners from ten countries, but it was not until 1956 that the first volumes of Lexique Stratigraphique International appeared. From a Swedish point of view, the Congress compelled Swedish geologists to carry out an inventory of the results of Swedish geological research of about half a century. The Congress was, in other words, an incentive to finish ongoing projects and bring together summaries of the major research areas. In the history of Swedish geo- sciences there is thus reason to speak about a pre- and a post-1910.

\section{Introduction}

During the first decade of the 20th century, geological research in Sweden reached a climax, both as compared with earlier advances in the discipline and its domestic status, and with the research in other countries. In a Swedish Encyclopaedia, the geologist Edvard Erdmann proudly wrote (1908; translated from the Swedish):

During recent decades, geological research in this country has been constantly improving and at the present time shows a vividness and interest in geology, mineralogy, and palaeontology, never previously exhibited. Especially in relation to Quaternary deposits and phenomena, these are studied with ever increasing success, so that within this branch of geology Sweden is in many respects leading and is showing the way for foreign researchers.

Such was at least the geologists' view of themselves and their work, which is not to say that the picture was correct or that it was shared by geologists in other countries. The image was, however, not just an expression of the nationalism of the time. During the preceding period, the geologists' research and writing had been especially intensive, the reason being the forthcoming 11th IGC meeting in Stockholm in August, 1910. As hosts for the meeting, the Swedish geologists were eager to piece together their many research results into a description of the country that was as complete as possible.

In addition to the basic idea of the IGC, to deal with general scientific issues that could hardly be decided within the individual nations, attention was focused on the geology of the country hosting each Congress. Through lectures about well-chosen subjects and instructive and enjoyable excursions, the geological and research assets of the host nations received special attention. These nations had, it was said, "derived considerable advantage" from hosting an IGC (Törnebohm, 1906) - and this advantage was attractive to prospective hosts.

Among Swedish geologists, there was thus a vision that the IGC should one day meet in Sweden. Professor Otto Torell, Director of the Swedish Geological Survey, had been one of the founders of the IGC in 1876 (Vai, 2002) and ever since, geologists in Sweden had attended meetings around the world. To be the hosting nation, however, was demanding; there must be things "grand enough" to show.

\section{The national background}

In the late 19th and the early 20th century, nature and the natural sciences played an important unifying role in Sweden, with the country being explored and studied by field scientists. From the $1850 \mathrm{~s}$ onwards, what could be called a minor revolution in the bio- and geosciences happened in Sweden. The economic incentives for 
research increased, as did the number of scientific societies, research institutions and stations, laboratories, committees, journals, and professional people. Systematically, extensive areas of the country were mapped. In addition, the great Swedish arctic expeditions were accomplished (Eriksson, 1978).

The rapid development of the earth sciences had several causes, e.g., the requirements of the mining industry and of the areal branches of industry and commerce, together with the increased knowledge required for industrial expansion. The search for natural resources and sources of energy attracted political support, and government and privately-financed research. That was very much the case in Norrland (the northern part of Sweden), which, with its abundance of water-courses (along which timber could be floated) and the extended railway lines, became more closely linked to the rest of Sweden (Sörlin, 1988). At the outbreak of World War I there were approximately $15,000 \mathrm{~km}$ of railway in the country.

Also technical know-how was much improved, thanks to economic investments in technical schools and a new generation of well-educated engineers. New technical processes in communication, fuel supply, water power, metallography, and for the production of pulp-paper, were worked out and used more efficiently. The exploitation of nature was looked upon as a prerequisite for the modernization of the country, and indeed was to become the basis for Sweden's well-being as an industrialized nation (Sundin, 1981).

In addition to incentives of public utility, national economy, and pure science, there was another, more nationalistic, ideal. Along with increased scientific knowledge, not only was the scientific standard of attainment raised, simultaneously the national economy and general welfare were strengthened. Scientific achievements, like a detailed national atlas and heroic polar expeditions, also emphasized the academic and cultural qualities of the nation. Some researchers, who had, in the minds of the public, succeeded in combining scientific research and remarkable achievements, such as Adolf Erik Nordenskiöld, Salomon August Andrée, and Sven Hedin, were embraced as national heroes (Frängsmyr, 1984).

In the fifty years prior to the 11th IGC several nationally oriented centres of learning were built in Stockholm, such as the National Museum of Fine Arts, the Geological Museum, the Nordic Museum, the Skansen Pleasure Garden, the Biological Museum, and the new Stockholm University building, all of which displayed Swedish culture, history, geology, flora, and fauna. The message was that nature had moulded Sweden, and in order to understand Sweden and the Swedes, one also had to understand nature itself (Nordlund, 1999).

\section{Initiative and organization}

That Sweden should host an International Geological Congress was suggested at an ordinary meeting with the Geological Society of Sweden on 6 April, 1905. The minutes reported that (translated from the Swedish):

The Chairman read the following communication:

'We, the undersigned, suggest that the Geological Society, by means of a committee elected from within the Society, should carry out a preparatory investigation of the possibilities and desirability that Sweden should issue an invitation for one of the forthcoming geological congresses.

Stockholm 25th March, 1905

A.G. Högbom, Henr. Munthe, Hj. Sjögren, Helge Bäckström, P.J. Holmquist, A.G. Nathorst, Gerhard Holm, G. Löfstrand, Fredr. Svenonius, Axel Hamberg, Axel Gavelin, Henrik Santesson, Carl Wiman, Herman Hedström, E. Svedmark, Rutger Sernander, Gerard De Geer, N. Olof Holst'... In reference to the received communication, Mr. Bäckström gave some information with regard to Sweden's position as to the Congress issue and suggested the appointment now of a committee of 7 people. After some discussion the Society decided to table the proposal at the May meeting.
The information given by Helge Bäckström probably included the fact that at the Paris Congress in 1900, Sir Archibald Geikie (Director of the Geological Survey of Great Britain) and Professor Giovanni Capellini (Director of the Geological Survey of Italy) had, on behalf of a great number of the Congress members, expressed the wish that one of the congresses should be held in Scandinavia in the near future. Such a desire had also been voiced at the Vienna Congress in 1903 .

When the tabled proposal was again discussed at the May meeting the Council suggested the Society should ask the following nine scientists to establish a committee to prepare a proposal, namely A.E. Törnebohm, A.G. Nathorst, G. De Geer, A.G. Högbom, G. Holm, J.C. Moberg, H. Lundbohm, H. Bäckström, and R. Sernander (see Figure 1). The Society accepted the suggestion and asked the committee to present its results before the end of the year.

At its first meeting on 11 May, the Preliminary Congress Committee, as it was called, mainly discussed the year for the Congress (there was an option of 3 or 4 years between the meetings). Some argued in favour of 1909, some were in favour of 1912, or even 1914. The committee finally decided that the Congress should be invited in 1910, unless Canada didn't express a wish to host the meeting after Mexico in 1906. At the second meeting, the chairman read letters from Canada and Scotland, declaring there were no plans for these countries to invite the next Congress. At that meeting it was also discussed how to finance a meeting in Stockholm, and some financial information about earlier congresses was presented.

The next Society meeting took place 2 November, 1905. The Preliminary Committee reported that the investigation was in progress, and that after several deliberations, and consideration of information received from abroad, the Committee had found it both feasible and desirable to invite the 11th IGC to be held in Sweden. Such an invitation had to be presented at the Congress in Mexico in 1906, but for such a decisive step to be taken it was first necessary to secure the required financial support by guarantees from private interests. However, in order to facilitate its endeavours in this respect, it seemed desirable that the Committee should be given full freedom of action in the preparations of the Congress. The Society decided accordingly.

Thereafter, the Preliminary Committee operated independently from the Society. From time to time, a Committee member reported briefly to the Society about its work. In November, 1905, the Committee sent out a printed memorandum to a broader audience, presenting the general idea about inviting the Congress to Stockholm and asking for financial support to cover the costs, then estimated at about SEK 50,000 (approximately $€ 250,000$ ). At the Committee's meeting in February, 1906, it was reported that private funds had been guaranteed to an amount of SEK $15,000-16,000$ and that Jernkontoret (the Iron Masters' Association) promised 10,000. It was then decided to request a Government grant of 20,000, and a submission to Parliament, dated 23 March, focused on the international development of sciences but also stressed the national importance. Sweden had, it was claimed, its "ranking position among nations" to defend. Also the on-going termination of the union with Norway was indirectly mentioned:

The applicants [i.e. the Preliminary Committee] hoped that the state authorities would fully value the importance that Sweden, especially under the present circumstances, should not neglect this favourable opportunity to uphold its position among the civilized nations and to maintain its glorious traditions in the spheres of natural sciences and mining operations.

The request was unanimously approved by Parliament, and at the IGC in Mexico 1906, the Swedish delegate Professor Hjalmar Sjögren officially invited the geological research community to Stockholm in 1909 or 1910 . The year 1910 was not definitely decided until November, 1906, partly because Belgium had also expressed interest in inviting the Congress in 1909, but after correspondence between the Swedish Committee and Belgian representatives, Belgium withdrew its invitation. Another reason was that the British Association for the Advancement of Science was to meet in Winnipeg in 1909. 


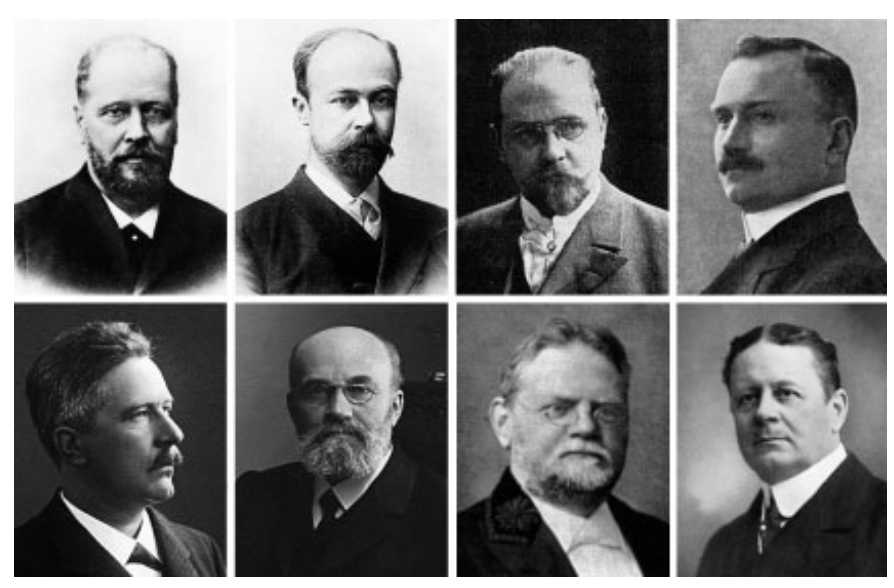

Figure 1 Some of the prominent members of the Congress organizing committee. Upper row from the left: Alfred $E$. Törnebohm, Chairman of the Executive Committee 1907, Honorary Member of the Congress; Gerard De Geer, who succeeded Törnebohm as Chairman of the Executive Committee 1907, and President of the Congress; Helge Bäckström, Treasurer of the Executive Committee, Treasurer of the Congress; Johan Gunnar Andersson, Secretary of the Executive Committee, and Secretary General of the Congress. Lower row from the left: Arvid G. Högbom, Member of the Executive Committee; Alfred G. Nathorst, Honorary Member of the Congress; Gerhard Holm, Member of the Executive Committee; Hjalmar Sjögren, Member of the Executive Committee (for further presentations, see Appendix 1).

During 1906, the Preliminary Committee was enlarged by the election of Johan Gunnar Andersson as Secretary, and Hjalmar Sjögren and Otto Nordenskjöld as Members (see Figure 1). In March 1907 this group of eminent geologists and administrators arranged a meeting of both practitioners and patrons of geology at Jernkontoret in Stockholm. The main issues on the agenda were: (1) to formally constitute an executive committee for arranging the Congress, and (2) to decide on the general features of the programme for the Congress and the associated field excursions. The Preliminary Committee had suggested that the Congress should concentrate on: (1) "issues that could be illustrated by geological phenomena in Sweden", such as the geology and ores of the crystalline basement, overthrust mechanics, the Lower Palaeozoic, the Ice Ages, and the Quaternary changes of level; (2) "geology of the Polar areas", because of the leading role that Swedish researchers had taken in that field; and (3) "the area of practical geology". In addition, the committee suggested "extensive and numerous" excursions, before, during, and after the Congress.

The meeting decided that all members of the Preliminary Committee were appointed to the Executive Committee, with Törnebohm as Chairman, Andersson as Secretary, and Bäckström as Treasurer. As regards the programme and excursions, these issues were in principle approved as suggested. In May, 1907, Törnebohm resigned from the Committee, De Geer was elected new Chairman, and Walfrid Petersson was elected new member. Later, Nathorst resigned from the committee and was replaced by Gunnar Andersson. At that time it also became clear that the costs for preparing the Congress would become higher than estimated, primarily because of the planned exhibitions and the many guides and summary reviews of parts of Sweden. The Secretary calculated that an additional SEK 15,000 would be needed.

In 1908, propositions were made about setting up a temporary Polar exhibition and that many additional guides and monographs should be written and translated. In the autumn of that year the Secretary calculated an additional amount of SEK 20,000 was needed to cover the unforeseen costs. It was decided to again turn to the Government for another 13,500 , and to the Geological Society to ask

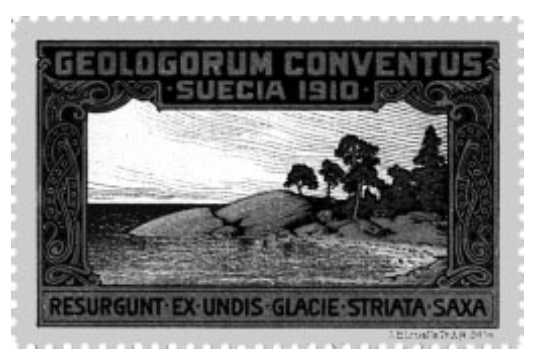

Figure 2 A non-value stamp used at the Congress. The lower text reads "glacially striated rocks resurgent from the sea". The stamp is 53 by $35 \mathrm{~mm}$ and printed in colour.

them to print the guides in the Society's Transactions (i.e. Geologiska Föreningens i Stockholm Förhandlingar GFF). The application to the Government was approved in 1909. So also was the proposal to the Society, though not, however, to the extent that the Committee had hoped. Late in 1908, the chairman of the Society read a communication from the Executive Congress Committee, asking the Society to print and defray the scientific excursion guides in $G F F$. The Council of the Society was in favour of the proposal, provided that the costs did not exceed those of an ordinary annual volume. The issue was tabled at the next meeting, which was held early in 1909. After a long debate for and against the proposition, the Society decided to support the proposal of the Executive Committee with the limitation suggested by the Council. This decision, however, came to be a recurrent issue for many years after the Congress since the allocated sum amounted to only about a tenth of the final costs, creating friction between the Congress leaders and the Society as to how to share the costs. (The dispute can be followed in the Society's records for almost a decade.)

\section{The implementation of the congress}

The official opening of the 11th IGC took place on Thursday 18 August, but already in the evening before there was a welcome party arranged by the Geological Society at the Grand Hôtel Royal, attended by about 650 delegates.

A Stockholm newspaper reported from the opening:

It is an honour for the geologists of Sweden to welcome prominent foreigners, but there is probably reason to say that they will travel to our country with joy and admiration to see for themselves the varied interesting things our country has to offer and the splendid way in which they are here being investigated. If today Sweden has a leading position in any branch of science, it is undoubtedly in geology. The Swedish crystalline basement, the Swedish ores, and the Swedish Quaternary deposits are here studied in a manner that has attracted worldwide attention, as has the way we have made geological investigations in the Arctic and Antarctic regions. (Dagens Nyheter, 17 August, 1910, translated from the Swedish).

In the presence of representatives of the Royal Family and the Government the Congress was opened in the flower-garlanded Royal Academy of Music, with about 700 Congress members present from all continents. The opening speech was given by the Congress President, Professor Gerard De Geer, who formally welcomed "the Congress members to a country that, admittedly, lacks so many of the normally occurring geological formations but instead has had the privilege of the combination of the Quaternary glaciation and the crystalline basement plateau setting the stage for the major continental changes of level so clearly demonstrated and so well preserved thanks to the resistant material of the basement rocks" (Dagens Nyheter, 19 August, 1910, translated from the Swedish).

The Congress was a major achievement with its speeches, lectures, meetings, festivities, and excursions. Also, a non-value stamp and Congress postcards with geological and Congress-related motifs were printed as souvenirs of the occasion (see Figures 2, 3). That the Congress was successful was corroborated by many. Speaking on behalf of the foreign members of the Congress, the British Survey Director Jethro Teall, and Professors Charles Barrois and Franz Beyschlag, thanked the Swedish hosts. Dr Teall said, inter alia, that the Congress had been "an unqualified success" partly because of 
"the energy, ability and enthusiasm of our Swedish colleagues and last but not least the cordial welcome which has been extended to us by all classes of society", and he extended thanks to the organizers "for the many services they have rendered in organizing the business of the Congress, in conducting the excursions and in preparing that most valuable compendium of Swedish geology-the Livret Guide"(Compte rendu, p. 117). A Swedish magazine described the Congress as "a real triumph", not only for the world-famous geologists of Sweden "but for our entire nation". From that point of view, the Congress indeed embodied the relations between science and nationalism.

\section{General meetings}

Two lectures were presented at the opening session. Professor De Geer's opening address, "A geochronology of the last 12,000 years", has become a classic. The endeavour to construct a time scale for the post-glacial period, based on the varved clay deposits, had been started by De Geer back in the 1880 s. His basic idea was that these clay/silt layers were annual deposits of some extension so that any layer could be identified by its thickness at localities several, or tenths of kilometres apart. In 1904 he had been able to demonstrate a large number of new measurements, primarily from the Stockholm area. The following summer, diggings were made in the area south of Stockholm and north of Uppsala. The results were most promising, and De Geer and his co-workers started to systematically measure varved clay deposits in many areas in the country in order to establish what he called "the Swedish time scale". About a year before the Congress he had completed an almost continuous line of measurements from Skåne in southernmost Sweden to Ragunda in the north, a distance of about $800 \mathrm{~km}$. De Geer's efforts to connect his scale to the historical chronology was successful (he thought) when, in August 1909, he tested the idea on a former river bed at Ragunda, which was known to have been exposed in the year 1796. (Later research showed, however, that this connection was incorrect, and it was not until 1984 that the definitive connection of De Geer's scale with the present was achieved. See Cato [1987]).

Professor Van Hise's opening address, "The influence of applied geology and the mining industry upon the economic development of the world", dealt with the conservation of natural resources, mainly iron and coal. He discussed, among other things, how long the coal deposits of the various nations were likely to last, and thought that if the consumption continued to accelerate, the coal of most countries would not last longer than a century, but if the amount of coal then consumed each year was to be mined, the coal would last for England and Germany between 500 and 1000 years and for the United States about 6000 years. He assumed that within a few hundred years many nations would be obliged to turn to sources of power other than coal, and that the power of falling water was the only certain one which would be available in large quantity continuously. Van Hise concluded that "the great drafts upon the mineral resources have been in the latter half of the 19th century" and that "for coal, iron and some other metals more material had been taken out of the ground during the past fifty years than in all previous ages". Because of the "possibility of the exhaustion of the metallic ores within a not remote time", Van Hise concluded that "the metals should be used with the utmost economy, that mining should be done without waste, that the metals should be [extracted] from the ores with as little loss as possible, and that when reduced to the metallic form they be conserved in order that metals may be available to the people through hundreds of generations to come". Van Hise was, it appears, an early proponent for a 're-cycling society'.

There were six themes at the Congress: 'Iron ore resources of the world', 'Post-glacial climatic changes', 'Glacial erosion', 'The sudden appearance of the Cambrian fauna', 'Geology of the Precambrian systems', and 'Geology of the polar regions'.
The first two topics had been thoroughly prepared by the Congress organizers by making world-wide inquiries and invitations to each country to submit a national report. This was a novel experience in the tradition of the IGCs and, as we will find, became a standard procedure for the following 25 years. The reports, edited by the Secretary-General, J.G. Andersson, were published at the Congress. The report Iron Ore Resources of the World, included 64 papers in two volumes of nearly 1100 pages and an Atlas volume with 43 maps. The other one, Die Veränderungen des Klimas seit dem Maximum der letzten Eiszeit [Climate changes after the peak of the last Ice Age], included 50 papers in a 460-page book (for contents of both titles, see Appendix 2).

Nine papers were read at the iron ore theme meeting, of which two, by K. Inouye (Japan), reported on iron ores in China and Southern Manchuria, lending no support to then current opinion that China was in possession of very great iron ore resources. H. Sjögren, in summarizing the principal results of the iron ore inquiry, discussed the probability of finding new iron ores in the less thoroughly investigated countries. He calculated, by means of an "iron coefficient", that the entire quantity of metallic iron on the surface of the earth, both actual and potential, would amount to about 425,000 MT, as compared to the then reported amount of 63,330 MT (today's figure is about 103,000 MT). Another paper of interest was by J.F. Kemp (USA) on the future of the iron industry, especially in North America, in which he also discussed the substitution of other materials for iron and steel in the future and mentioned cement as a candidate to supplant structural steel. He continued: "In the form of reinforced concrete, cement is a material which grows in favour and in use. Some steel is of course a component and the cement is thus only in part a substitute, but its potentialities are sufficient to justify its mention" (Compte rendu, p. 328). He also stressed the need for an international inventory of the coal resources of the world, and so did J.W. Richards (USA) in a following paper. (Such an inquiry was carried out by the Executive Committee of the 12th IGC in Canada.)

There were a handful of papers read at the Climate Change meeting. G. Andersson, initiator of the published inquiry, gave a summary review of the results in concluding that the fragmentary character of the report mirrored the fragmentary knowledge in this field, and that the report made up a firm basis for further research One of the many papers in the report that should be mentioned was the one by R. Sernander (Sweden) on post-glacial climatic changes evidenced by studies of peat bogs, later confirmed by pollen analysis. E. Brïckner (Austria) concluded that the primary cause for the climate change during the Quaternary must be related to changes in temperature, and that a theory explaining the phenomenon must await future research.

The glacial erosion theme was a controversial issue because the question was whether a glacier causes any major erosion or rather is a protective agent. A.G. Högbom (Sweden) advocated the erosive power of ice, but admitted difficulties in explaining some valleys that had been ice-filled but their soft, pre-glacial deposits had not

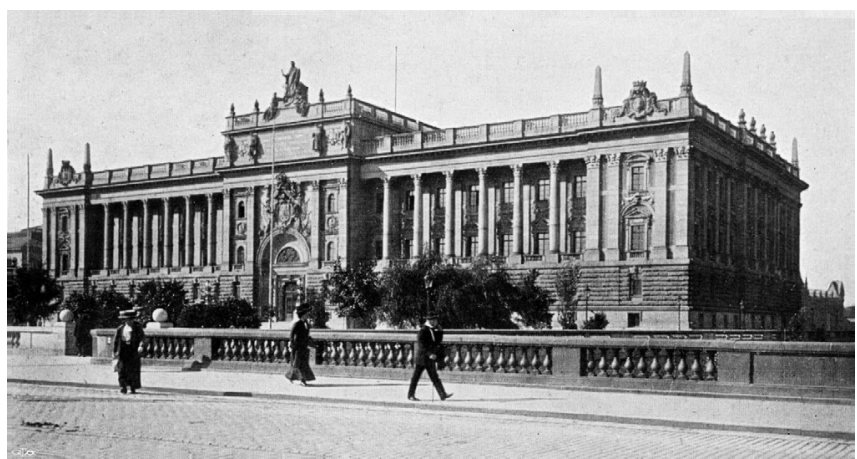

Figure 3 The newly built Parliament Building in central Stockholm was the headquarters of the 11th IGC, and most of the meetings and discussions took place in the halls of the Upper and Lower Houses. This is one of several postcards printed for the Congress and distributed to its members. 
been removed. A. Penck (Germany) presented the evidence, especially overdeepening and the U-shaped form, which had led him to conclude that the Alpine valleys to a large extent had been formed by the action of ice. W.M. Davis (USA), in a written communication, stressed the importance of landform analysis for the understanding of the development of any landscape. Additional talks demonstrated the glacial origin of fjords.

The theme of the sudden appearance of the Cambrian fauna attracted about ten speakers. J.J. Sederholm (Finland), C. Barrois (France), and A. Rothpletz (Germany) presented evidence for preCambrian life, which was generally accepted by the audience. Other papers (W.J. Sollas, R.A. Daly, J. Walther, J.W. Evans) did not question the existence of life before the Cambrian, but discussed the sudden appearance of shelly fossils in the Cambrian in terms of shortage of lime and other substances in the pre-Cambrian sea water, that hard parts had been dissolved due to acid sea bottom conditions, or a sudden need for protective hard parts at that time due perhaps to the appearance of carnivorous animals.

The theme of the geology of the Precambrian systems was divided into two parts, the first of which was "the evidences for deep metamorphism of the Precambrian crystalline schists". F.D. Adams (Canada), J.J. Sederholm (Finland), and C. Barrois (France), among others, demonstrated the formation of crystalline schists by granite injections or the intrusion of granitic batholiths, and the occurrence of regional anatexis. The second subject was "the principles for a classification of the Precambrian terrains". Lectures were given by, for instance, W.G. Miller (Canada) on the principles of classification used in Ontario, by J.J. Sederholm (Finland) on the subdivision of the pre-Cambrian of Fennoscandia, and by J.F. Kemp (USA) on PreCambrian formations in the State of New York.

The fifth theme was concerned with the geology of the polar regions. Among the several lectures, one should mention particularly that by A.G. Nathorst (Sweden), who discussed his and others' researches on the fossil floras of the Arctic region, and demonstrated its former temperate and sub-tropical climatic conditions. O. Nordenskjöld (Sweden), leader of the Swedish Antarctic Expedition 1901-1903, described the many similarities between the bedrock of southern South America and adjoining area of Antarctica, and pointed out the presence of a submarine arc linking the two areas, as demonstrated by J.G. Andersson's map of the seabed contour. Reports were also given on the British Antarctic Expedition 1907-1909, and two French expeditions in 1903-1905 and 1908-1910.

\section{Section meetings}

There were five section meetings, the first on general and regional geology and tectonics, the second on petrography and mineralogy, the third on stratigraphy and palaeontology, the fourth on glaciers and Quaternary phenomena, and the fifth on applied geology. Probably the most interesting lecture of the first section was that by H.F. Reid (USA) on faults and earthquakes, in which he presented his idea of the cause of the San Francisco earthquake: "Tectonic earthquakes are the result of elastic strains set up by slow differential movements of neighbouring areas, which finally become so great that the rock fractures, and the two sides of the fracture spring back under their own elastic forces to new positions of equilibrium" (Compte rendu, pp. 122-123). The following year, this idea was presented as the epoch-making elastic-rebound theory. Among the papers presented at the meetings of the second section, two lectures should be mentioned. F.D. Adams (Canada) described his pioneering experimental investigations of the flow of rocks, under various temperatures and pressures (that profoundly came to influence our understanding of metamorphic processes), and W. Cross (USA) discussed, in the light of some criticism it had met, the quantitative but cumbrous chemical-mineralogical classification of igneous rocks, developed by himself, J.P. Iddings, L.V. Pirsson, and H.S. Washington (now commonly referred to as the C.I.P.W. system).
The meetings of the third section, on stratigraphy and palaeontology, started with two lectures by A.W. Grabau (USA), one dealing with the division of the North American Silurian (i.e., Ordovician and Silurian) and the other on continental formations in the North American Palaeozoic. Two other talks, given much credit by the audience, were delivered by C. de la Torre (Cuba), presenting proof for the existence of Jurassic beds on Cuba and for a continental Pleistocene fauna in central Cuba.

Among the lectures given in the section on glaciers and Quaternary phenomena, one dealing with pre-Quaternary glaciations was specially interesting. A.P. Coleman (Canada) discussed, and demonstrated with some striated stones, a Lower Huronian ice age in Canada, a conclusion enthusiastically accepted by several colleagues present, who also declared the onset of renewed research for similar deposits in their home countries. Of the lectures given in the section on applied geology one could mention that by W. Petersson (Sweden), in which he gave an interesting review of Swedish mining maps, the first of which appeared in 1629, and mine-surveying methods; and that by P. Krusch (Germany) on some finds of radium in rocks and the future of the radium market.

\section{Proposals}

Eight proposals were presented to the Congress. One applied to the construction of a standard geological map of the world on the scale of $1: 1,000,000$, submitted by the United States Geological Survey through its Director G.O. Smith. The Congress decided that a committee of five members should consider the proposal and present a proposal at the next Congress.

The second proposal "International cooperation for study of fractures in the earth's crust" was presented by W.H. Hobbs (USA), the motivation being that these fractures "have acquired a new significance from the now somewhat general acceptance of the view that earthquakes have their origin in the movements which occur on planes of fracture" (Compte rendu, p. 167). The Congress recommended that the Executive Committee of the next Congress (Canada) to make an international inquiry of the fracture systems of the earth's crust and publish a report similar to those presented by the Executive Committee of the Stockholm meeting. (This was not carried out.) A proposal to establish an international institute for the exchange of geological objects, submitted by E. Stolley (Germany), was regarded as interesting but was not approved by the Congress Council for inclusion in the work of the Congress, but should be taken care of by private means. L. Waagen (Austria) proposed that the Congress should establish a commission for the publication of an international stratigraphic dictionary that would bring together the stratigraphical nomenclature of all nations. The proposal was approved, and a sub-commission was set up with commissioners from ten countries. G.F. Becker (USA) presented a proposal that the Congress should make a statement that "it is of great importance that systematic analyses should be made of the waters of those large rivers and lakes whose composition is as yet imperfectly known"(Compte rendu, p. 176). The Congress acted accordingly.

With reference to the inquiry presented at the Congress The Iron Ore Resources of the World, F. Beyschlag (Germany) proposed a continuation of the inventory of the world's iron ore resources from an economic point of view. The Council decided to establish a commission with that purpose.

I. Friedlaender (Italy) presented a proposal to set up a volcanological research institute in Naples. The council agreed with Dr Friedlaender that such an institute would be desirable, and decided that efforts should be made to try to interest different countries in the project. A proposal suggesting the establishment of an international commission for the study of fossil man, submitted by N.O. Holst (Sweden), was positively received by the Council, which decided to establish a committee that should consider the proposal and present a plan at the Congress in Canada. 


\section{Some congress results}

A most remarkable initiative by the Executive Committee was the world-wide inquiries of the resources of iron ore, published in The Iron Ore Resources of the World, and of climatic change, published in Die Veränderungen des Klimas seit dem Maximum der letzten Eiszeit. Such thematic, world-wide investigations thereafter came to be part of many IGCs, e.g., coal at the 12th, pyrites and phosphates at the 14th, gold at the 15th, and copper at the 16th IGC. L. Waagen's proposal to establish a commission for the publication of an international stratigraphic dictionary was approved, and a sub-commission was set up with commissioners from ten countries. Two world wars and a world depression later, the first editions of Lexique Stratigraphique International appeared in 1956.

From a Swedish point of view, the approaching Congress forced Swedish geologists to carry out an "Inventory Deed" (as one Swedish geologist called it) of the results about half a century of geological research in Sweden. Thus the Congress served as an incentive to finish on-going projects and, as thoroughly as possible, to bring together summaries of the major research areas. For instance, G. De Geer, in addition to the geochronological work, made a map of eskers, end-moraines, and glacial striations, including the highest coastline in southern Sweden; and he published "Quaternary sea-bottoms in western Sweden". A. Högbom wrote several of the major guides and (together with A. Gavelin) a paper on ice lakes of northern Sweden. H. Munthe published his major work on the late-Quaternary history of Gotland and, as one of the reviewguides of the late-Quaternary history of southern Sweden. H. Sjögren wrote five review guides of classic Swedish mines and miningfields, and J.C. Moberg made a major contribution in his review of the lower Palaeozoic of Scania.

The "summing-up" publications that resulted from the "Inventory Deed" became a starting point for continued research. They evidenced what had been achieved, and pointed at several flaws. In the history of Swedish geosciences there is thus good reason to speak about a pre- and a post-1910 (Nordlund, 2001a).

\section{Festivities}

In the evening of 17 August there was a reunion reception at the Grand Hôtel Royal in central Stockholm, hosted by the Geological Society of Sweden, with about 800 Congress members present. In the afternoon of 18 August all members of the Congress were invited to the Royal Palace by the King and Queen of Sweden, where also the Prime Minister and several other ministers and high officials were present. In the evening of 20 August, Professor Helge Bäckström invited about seventy members of the Mineralogic and Petrographic Section to his "magnifique villa" just outside Stockholm. Also Professor Hjalmar Sjögren arranged a party in his home (the manor-house of Nynäs, south of Stockholm) for 180 members of the Congress in the evening of 21 August. Those not invited at the Sjögren's went to Uppsala to a reception at the University.

The last party, on 24 August, was a farewell soirée suédoise at Skansen Pleasure Garden in central Stockholm. In the presence of about 700 Congress members, many speeches were made, one of the last being by Professor James F. Kemp, delegate of the Geological Society of America, of the New York Academy of Sciences, and of the Columbia University, New York, who said, inter alia:

We find ourselves amidst most appropriate surroundings for the closing exercizes of the Eleventh international Geological Congress. Stockholm with its myriads of flashing lights is spread out before us like an inverted, starry sky; and while the Swedish Capital has been fascinating by day, we feel it to be altogether enchanting by night. With a pang of regret we realize that our delightful days of scientific discussion and of open-handed hospitality have passed.

The greatest good of a scientific gathering like the Geological Congress is the cementing of friendships. We all come to know per- sonally the investigators whose works we have read and studied, and from whose writings we have received so much that was stimulating and instructive. After these associations later papers become living and personal, not contributions from a vague and indefinite source.

The geological exposures which we have seen in Sweden have been of the profoundest interest, and all who have come from other lands to view them and to learn the results garnered from them, by the Swedish geologists will return to their homes vastly benefited by the experience.... Few of us had ever seen such instructive exposures as the glaciated ledges which Sweden's islands and eastern coast afford (Compte rendu, pp. 232-233).

\section{Exhibitions}

The permanent exhibitions at the Geological Survey of Sweden, the Swedish Museum of Natural History, and Stockholm University were at that time situated in central Stockholm, and were easily accessible to the Congress members. Also, the Geological institutions at the University of Lund, in southern Sweden, and at Uppsala University, $60 \mathrm{~km}$ north of Stockholm, had been prepared for visitors. The Geological Museum of the Survey, in particular, was restored for the Congress. The exhibited objects were cleaned, new labels were produced, and new wall illustrations and pictures, showing unusual and interesting localities and phenomena were procured. Incomplete collections were replenished and a new guide to the museum was printed. The Curator wrote that the museum put on a festive attire for the Congress. "It wanted to greet the visits by the numerous foreign geologists in a dignified and attractive manner and give as clear as possible a picture of the geology of Sweden and the results of Swedish geological research" (Erdmann, 1916, translated from the Swedish).

Three temporary exhibitions were arranged for the Congress. The largest (and the most expensive) was the Polar exhibition, with an area of about $300 \mathrm{~m}^{2}$, divided into an "Antarctic Hall", showing rocks and fossils sampled by the Swedish Antarctic Expedition of 1901-1903 and parts of collections of Swedish expeditions to Patagonia, Tierra del Fuego, Falkland Islands, and South Georgia; and a "Spitzbergen Hall", showing the results of Swedish research on the island, including those of A.E. Nordenskiöld, O. Torell, A.G. Nathorst, G. De Geer, and J.G. Andersson (see Figure 4). Another exhibition illustrated the development of Swedish peat-bogs. The third showed Swedish magnetometry and mine surveying, consisting of mining maps, models of mines, magnetometric maps, and magnetic and mine surveying instruments.

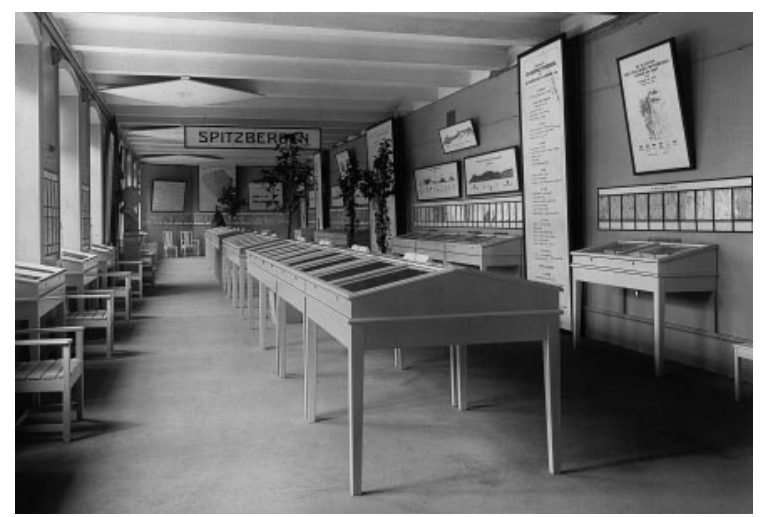

Figure 4 The Spitzbergen Hall of the Polar exhibition showed the results of the Swedish research on the island, which started as early as 1758. The exhibition had also an Antarctic Hall that showed rocks and fossils collected by the Swedish Antarctic Expedition 1901-03 and parts of collections of Swedish expeditions to Patagonia, Tierra del Fuego, Falkland Islands, and South Georgia. This exhibition was arranged by Lennart von Post, who later became well known as founder of the method of pollen analysis. 


\section{Economy}

The Preliminary Committee estimated, in 1905, the total cost for arranging the 11th IGC at about SEK 50,000 (approximately $€ 250,000$ ), later recalculated at about 85,000 , to finally land at almost 125,000 . This was not due to sloppy calculations but to an ever increasing degree of ambition to make the Congress a remarkable occasion, and also to a growing realisation among the members of the Executive Committee that the Congress was a golden occasion to get things done that normally would not have been done at all or would perhaps have been done in some distant future. This was especially the case of the excursion guide books, many of which were true monographs based on thorough compilatory work, but much field work as well. The volume of the guides became three times as large as planned.

The membership fee for Congress attendance was SEK 20 (approx. €92) and the fee for the several-days excursions varied between SEK 900 (€4160, to northern Sweden and Spitzbergen for 23 days) and SEK 45 ( $€ 210$, to see Rhaetic and Liassic rocks in Skåne for 3 days).

In the Compte rendu the balance sheet of the 11th IGC was given as below (equivalent values in Euro 2004 and percentages here added).

\section{Expenses}

Organization

Inquiries and surveys

Iron Ore Resources of the World

Postglaziale Klimaveränderungen

Exhibitions

Guide books

Excursions

Parties

Compte rendu

Total

Receipts

Swedish State

Rock- and mining Companies

Iron Masters' Association

Private donations

Geological Society of Sweden

Congress Membership fees

Guide books

Interest

Deficit

Total

1910 SEK 2004 EUR

$\begin{array}{rrr}32,600 & 140,000 & 26.1 \\ 6,900 & 29,700 & 5.5 \\ 2,500 & 10,700 & 2.0 \\ 6,300 & 27,100 & 5.1 \\ 11,500 & 49,500 & 9.2 \\ 46,100 & 198,300 & 37.0 \\ 1,800 & 7,700 & 1.4 \\ 2,100 & 9,000 & 1.7 \\ 15,000 & 64,500 & 12.0 \\ \mathbf{1 2 4 , 8 0 0} & \mathbf{5 3 6 , 5 0 0} & \mathbf{1 0 0 . 0} \\ & & \\ 33,500 & 144,000 & 26.9 \\ 25,000 & 107,500 & 20.0 \\ 17,000 & 73,100 & 13.6 \\ 15,400 & 66,200 & 12.3 \\ 2,100 & 9,000 & 1.7 \\ 15,700 & 67,500 & 12.6 \\ 6,000 & 25,800 & 4.8 \\ 2,700 & 11,600 & 2.2 \\ 7,400 & 31,800 & 5.9 \\ \mathbf{1 2 4 , 8 0 0} & \mathbf{5 3 6 , 5 0 0} & \mathbf{1 0 0 . 0}\end{array}$

\section{Field excursions}

A particularly time-consuming and expensive task was the detailed planning of the excursions, and to compile and print the scientific guides, in total about 1700 pages. Besides being guides to the excursion objects, the booklets served as geological overviews of larger areas. As mentioned, most of the guides were published in $G F F$ in 1909 and 1910. Interest in taking part in the excursions was generally much higher than expected. About 210 people participated in the pre-Congress excursions, and the same number took part in the postCongress excursions. In the excursions during the Congress, a total of at least 500 participated.

The largest and most expensive excursions were accomplished in the weeks prior to the Congress. Aboard the steamship Aeolus about 65 participants left for Spitzbergen on 25 July (see Figure 5). Other long excursions were made by special train through various parts of northern Sweden to see tectonic features, magmatic rocks, iron-ore deposits, the alpine region of Mount Sarek, and the Luleälven river valley. Shorter excursions studied the morphology and

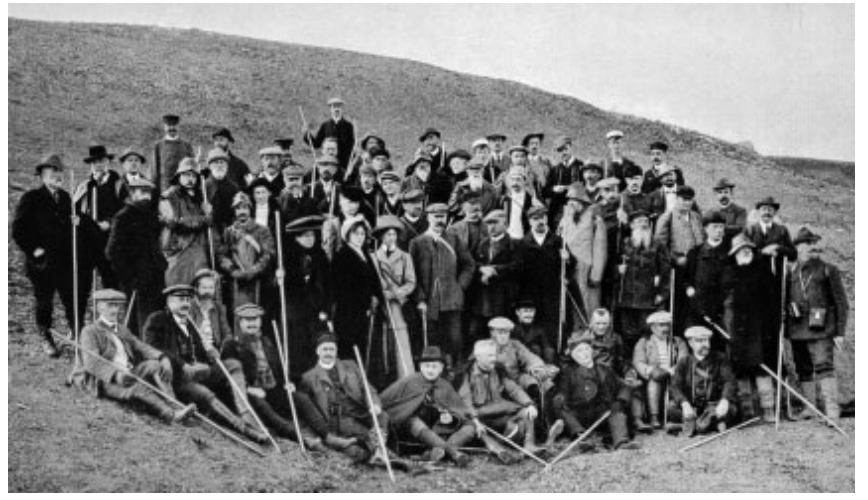

Figure 5 The Spitzbergen excursion party. Sitting far right is the guide Professor Gerard De Geer (from Compte rendu, facing $p$. 1226, with all participants identified).

Quaternary phenomena of Torneträsk, the Quaternary geology of Jämtland and Ångermanland, and the peat bogs of Närke.

Some accidents occurred. Professor Sapper from Strassburg was run down by a cyclist at the railway station in Åre and his left arm broken. A.G. Högbom, who was responsible for some excursions to northern Sweden, fell and broke an arm, and at Spitzbergen the Aeolus ran aground. Another remarkable episode was the blowing up of the "Minister" (Statsrådet), the highest peak of Mount Kiirunavaara, which happened on 10 August. The mountain was, according to Compte rendu, "sacrificed in honour of the geologists"!!

Land elevation was among the phenomena that could not escape the notice of the excursion parties. In the guide to the Quaternary geology of northern Sweden, A.G. Högbom emphasized that "The absolute maximum, also the maximum of the entire Fennoscandian uplift area, 284 metres, is recorded on Mount Skuluberget between Hernösand and Örnsköldsvik". The conditions at Skule (as spelled today) were by then also known outside the domains of Swedish geology, and the place has since become a shrine for researchers interested in land uplift. The area ("The High Coast") was given status of World Nature Heritage in 2000, the first of its kind in northern Europe (Nordlund, 2001b).

There were also excursions during the Congress, most over a single day. Objects for visits were Archaean rocks and Quaternary phenomena in the Stockholm area; the morphology and Archaean bedrock of the Stockholm archipelago; and Quaternary deposits in the Uppsala area. A 36-hour tour was also made to Gotland (in the Baltic Sea) to see the island's famous Silurian exposures.

After the Congress there were eight excursions. While the preCongress tours mainly went north, the post-Congress excursions concentrated on central and southern Sweden. They lasted between one and two weeks. In central Sweden, the Archaean bedrock, metalliferous ore deposits, the morphology, Quaternary phenomena, Silurian deposits of Gotland and Lower Palaeozoic deposits in Dalarna and Västergötland were visited. In Skåne (southernmost Sweden), Lower Palaeozoic, Rhaetic, and Liassic deposits, and Cretaceous exposures were visited.

\section{Attendance}

According to the preliminary Liste générale des Membres et de Délégations of the 11th IGC, which was printed for the meeting, the total number of registered individual participants was 744 . In the Compte rendu, published in 1912, the number of finally registered and the number of individual participants who attended were 879 and 625, respectively, from 37 countries and six continents. Among those present, 550 were from Europe (Austria 30, Belgium 8, Bulgaria 2, Denmark 20, Finland 15, France 33, Germany 127, Great Britain 38, Greece 1, Hungary 17, Italy 14, The Netherlands 11, Norway 8 , Portugal 1, Romania 6, Russia 35, Spain 4, Sweden 170, 
Switzerland 9, Turkey 1), 60 from North America (Canada 5, Cuba 1, Mexico 3, USA 51), 8 from Asia (China 1, India 1, Japan 6), 4 from Africa (Algeria 1, Egypt 3), 2 from South America (Argentine), and 1 from Australasia (Australia).

\section{Publications}

(See Appendix 2 for details.)

The Iron Ore Resources of the World. An Inquiry made upon the initiative of the Executive Committee of the XI International Geological Congress, Stockholm 1910, with the assistance of Geological Surveys and Mining geologists of different countries. Edited by the General Secretary of the Congress. 2 text-volumes of 1068 pp. and an Atlas of 43 maps. Generalstabens Litografiska Anstalt, Stockholm, 1910.

Die Veränderungen des Klimas seit dem Maximum der letzten Eiszeit. Eine Sammlung von Berichten unter Mitwirkung von Fachgenossen in verschiedenen Ländern. Herausgegeben von dem Exekutivkomitee des 11. internationalen Geologenkongresses durch dessen Generalsekretär. 459 pp. Generalstabens Litografiska Anstalt, Stockholm, 1910.

Guide de l'excursion au Spitzberg /A geological excursion to Central Spitzbergen by Gerard De Geer, 23 pp. Stockholm, 1910.

Livret Guide. Guides des excursions en Suède / Guides to excursions in Sweden, 1-40. 1730 pp. Stockholm, 1909-1910.

Compte rendu de la XIe session du Congrès Géologique International (Stockholm 1910). 2 volumes. 1413 pp. Stockholm, 1912.

\section{Acknowledgements}

We are grateful to David Oldroyd (Sydney, Australia) for scrutinizing our manuscript and suggesting improvements, and to Isabel Dyck (Cambridge, UK) for linguistic corrections.

\section{References and sources}

In addition to the Congress publications, listed above, the following publications have been consulted:

Anonymous, 1910, The Geological Congress at Stockholm: Nature, v. 84, 1910 , pp. $440-443$.

Cato, I., 1987, On the definitive connection of the Swedish Time Scale with the present: Sveriges Geologiska Undersökning, ser. Ca, no. 68 .

Dagens Nyheter 10, 14, 15, 17, 20, 21, 22, 23, 24, 25, 26, 28, 30 August, and 1 September, 1910.

Erdmann, E., 1908, Geologi, in Nordisk Familjebok, 2nd edn, p. 977.

Erdmann, E., 1916, Sveriges geologiska undersöknings museum, dess första anläggning, samt tillväxt, innehåll och utseende m.m. före flyttningen till Frescati 1915: Sveriges Geologiska Undersökning, ser. C, no. 265.

Eriksson, G., 1978, Kartläggarna. Naturvetenskapens tillväxt och tillämpningar i det industriella genombrottets Sverige 1870-1914: Umeå Studies in the Humanities, v. 15.

Frängsmyr. T., 1984, Vetenskapsmannen som hjälte. Aspekter på vetenskapshistorien: Stockholm: Norstedt.

Hobbs, W.H., 1910, The International Geological Congress at Stockholm: Science, n.s., v. 32, no. 821, September 23, pp. 413-416.

Nordlund, C., 1999, Organising geology for display. The Museum of the Swedish Geological Survey, 1871-1915: Nordic Museology, no. 2, pp. $111-130$.

Nordlund, C., 2001a, Det upphöjda landet. Vetenskapen, landhöjningsfrågan och kartläggningen av Sveriges förflutna, 1860-1930: Kungl. Skytteanska Samfundets Handlingar 53.

Nordlund, C., 2001b, 'On going up in the world', nation, region and the land elevation debate in Sweden: Annals of Science, v. 58, pp. 17-50.

Sörlin, S., 1988, Framtidslandet. Debatten om Norrland och naturresurserna under det industriella genombrottet: Kungl. Skytteanska Samfundets Handlingar 33.

Stockholms-Tidningen 18, 19, 22, 26 August, 1910.

Sundin, B., 1981, Ingenjörsvetenskapens tidevarv. Ingenjörsvetenskapsakademin, Pappersmassekontoret, Metallografiska institutet och den teknologiska forskningen i början av 1900-talet: Umeå Studies in the Humanities 42.

Svenska Dagbladet 18, 19, 20, 21, 22, 23, 24, 25, 26 August, 1910.

Törnebohm, A.E., 1906, XIe Internationella Geologkongressen, Stockholm 1910. (printed letter of information and invitation to support the implementation of an IGC in Stockholm 1910; dated "Stockholm Dec. 1906"). Törnebohm, A.E., 1907, Organisationsförsamlingen för den Elfte Internationella Geologkongressen i Stockholm 1910 (printed letter of invitation to participate in the general layout of the IGC in Stockholm 1910; dated "Stockholm Febr. 1907").

Vai, G.B., 2002, Giovanni Capellini and the origin of the International Geological Congress: Episodes, v. 25, pp. 248-254.

Also non-published materials have been consulted, kept at the archives of the Geological Survey of Sweden (Uppsala), the Geological Society of Sweden (housed at the Survey), and the Royal Swedish Academy of Sciences (Center for History of Science, Stockholm).

\section{Appendix 1. The congress organizers}

Andersson, Gunnar (1865-1928), Member of the Executive Committee. Botanist and geographer, Professor of Economic Geography at the Stockholm School of Economics 1909-1928. Papers on the history of plant geography of Sweden.

Andersson, Johan Gunnar (1874-1960), succeeded Bäckström as Secretary of the Preliminary Committee 1906, Secretary of the Executive Committee, and Secretary-General of the Congress. Geologist and archaeologist. Director of the Geological Survey of Sweden 1906-1914, adviser to the Chinese Government and the Chinese Geological Survey 1914-1924, Professor of Geology at Stockholm University 1924-1926, Professor of East Asian Archaeology in Stockholm 1926-1939. Several expeditions in the Arctic area in the 1890s, second commander of the Swedish Antarctic Expedition 1901-1903.

Bäckström, Helge (1865-1932), Secretary of the Preliminary Committee 1905, Treasurer of the Preliminary Committee and of the Executive Committee, Treasurer of the Congress. Geologist, politician, and businessman. Professor of Mineralogy and Petrography at Stockholm University 1908-1914. Papers on mineral chemistry, crystallography, rock genesis, and metamorphosis. Member of Parliament 1912-1921.

De Geer, Gerard (1858-1943), Vice Chairman of the Preliminary Committee, succeeded Törnebohm as Chairman of the Executive Committee 1907, and President of the Congress. Baron, geologist, and explorer, served at the Geological Survey of Sweden 1878-1897, Professor of Geology at Stockholm University 1897-1924. Chancellor 1902-1910 and Vice-Chancellor 1911-1924 of Stockholm University, and Member of Parliament 1900-1905. Founder of the Swedish Geochronological Institute. Papers on glacial geology, geochronology, and climate change. De Geer is a well-known name in Swedish history of science and ideas. He made six expeditions to Spitzbergen between 1882 and 1910.

Högbom, Arvid G. (1857-1940), Member of the Preliminary Committee and of the Executive Committee. Geologist, Professor of Mineralogy and Geology at Stockholm University 1895-1896 and at Uppsala University 1896-1922. Papers on Quaternary geology, the Scandinavian Caledonides, and on the Swedish crystalline basement, including several extensive regional descriptions. Many papers also on physical and cultural geography, archaeology, and on history of the geological sciences.

Holm, Gerhard (1853-1926), Member of the Preliminary Committee and of the Executive Committee. Palaeontologist and geologist, served at the Geological Survey of Sweden 1887-1901, Keeper and Professor of Palaeozoology at the Swedish Museum of Natural History in Stockholm 1901-1923. World-wide reputation as an invertebrate fossil specialist. Systematic papers on, mainly, trilobites, graptolites, and orthocone cephalopods.

Lundbohm, Hjalmar (1855-1926), Member of the Preliminary Committee and of the Executive Committee. Geologist and industrialist. Served at the Geological Survey of Sweden 1879-1902, and at the LKAB Mining Company 1898-1920 and Manager from 1900. 
Moberg, J. Christian (1854-1915), Member of the Preliminary Committee and of the Executive Committee. Geologist and palaeontologist, Professor of Geology and Mineralogy at Lund University 1895-1915. Papers on Mesozoic (e.g. belemnites) and Palaeozoic (e.g. trilobites and graptolites) fossils and rocks of Skåne (southernmost Sweden), and geological descriptions of that province as well as of the Lower Palaeozoic of Sweden.

Nathorst, Alfred G. (1850-1921), Member of the Preliminary Committee, Honorary Member of the Congress. Geologist and palaeontologist, served at the Geological Survey of Sweden 1873-1884, Professor of Palaeobotany at the Swedish Museum of Natural History 1884-1917. Papers on botany, zoology, palaeozoology and geography and, especially, on geology and palaeobotany rendered him international fame. Led several expeditions to the Arctic Ocean for studies on, e.g., Spitzbergen and Greenland.

Nordenskjöld, Otto (1869-1928), Member of the Preliminary Committee and of the Executive Committee. Geologist, geographer, and explorer, Professor of Geography and Ethnography at Göteborg University 1905-1928. Papers on glacial geology and morphology. Expeditions to South America, northwest Canada, and Greenland, commander of the Swedish Antarctic Expedition 1901-1903.

Petersson, Walfrid (1862-1933), Member of the Executive Committee. Geologist, served at the Geological Survey of Sweden 1890-1901, Professor of Mining Science at the Royal Institute of Technology in Stockholm 1901-1929 and Director of the School of Mining 1903-1927. Papers on minerals, Swedish iron ores, and mining fields.

Sernander, Rutger (1866-1944), Member of the Preliminary Committee and of the Executive Committee. Botanist and Quaternary geologist, Professor of Phytobiology at Uppsala University 1909-1931. Papers on plant migration biology, post-glacial development of climate and plants in Scandinavia.

Sjögren, Hjalmar (1856-1922), Member of the Preliminary Committee and of the Executive Committee. Geologist and mineralogist, Professor of Mineralogy and Geology at Uppsala University 1889-1894, Professor of Mineralogy at the Swedish Museum of Natural History 1901-1922. Papers on minerals, mines, and geology of iron ores. A man of means, he also devoted himself to patronage of the arts.

Törnebohm, Alfred E. (1838-1911), Chairman of the Preliminary Committee and Chairman of the Executive Committee 1907, Honorary Member of the Congress. Geologist, served at the Geological Survey of Sweden 1859-1874, reader at the Royal Institute of Technology in Stockholm 1878-1897, Director of the Geological Survey of Sweden 1897-1906. Papers on the crystalline basement rocks of Sweden, structural geology and tectonics of the Scandinavian Caledonides, and ore geology.

\section{Appendix 2. The 11th IGC publications}

A specification of all 11th IGC-related publications, with lists of contents, produced before and after the Congress is available as a PDF document from: bjorn.sundquist@swipnet.se

\begin{abstract}
Dr. Björn Sundquist received a Ph.D. in Historical Geology and Palaeontology at Lund University in 1982. He worked for the Geological Survey 1984-1985, and entered the Board of the Geological Society of Sweden in 1985. He served as the editor of the Society's journal Geologiska Föreningens i Stockholm Förhandlingar (GFF) 1985-2001. He founded and served as the editor of the Society's popular science journal Geologiskt forum 1994-2001 and of the Society's Web-site 1997-2001. He is a Member of INHIGEO since 2000, and now runs the Scientific Biography Center in Uppsala.
\end{abstract}

Dr. Christer Nordlund holds a lectureship in Environmental History at Umeå University, where he received his Ph.D. in History of Science and Ideas in 2001. He worked for the Swedish Reseach Council in 2002, was a Visiting Rausing-Scholar at the Office for History of Science, Uppsala University, in 2003, and was, in 2004, a Visiting Scholar at the Dept. of History and Philosophy of Science, Cambridge University, and a Visiting Fellow at Clare Hall. His stay in England was sponsored by The Swedish Foundation for International Cooperation in Research and Higher Education (STINT). He is a Member of INHIGEO since 2000.
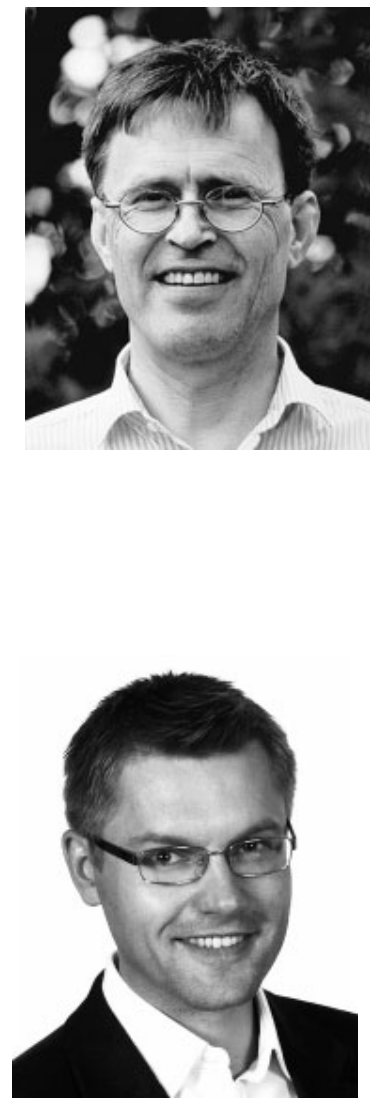

\section{CALL FOR PAPERS}

Episodes is the quarterly science and news journal of the International Union of Geological Sciences (IUGS). It focuses on the publication of results of scientific research and other information addressing issues of interest to the global earth-science community. Special emphasis is given to topics involving geological aspects of population growth and economic development and their resulting impacts on or implications for society. As the principal publication of the IUGS, Episodes also carries information about IUGS scientific programs and activities to the extent necessary to communicate effectively with the worldwide IUGS constituency.

Contributions of the following types of manuscripts are here solicited:

- scientific articles

- conference reports

- news and views

- letters to editor

- book reviews

- information on training courses (especially those geared to participants from developing countries)

- noteworthy new publications, including national or regional geologic maps

Please address all contributions to: The Editor Episodes

P. O. Box 823, 26 Baiwanzhuang Road 100037 Beijing, CHINA

Tel: +86-10-68320827, +86-10-68329084

Fax: +86-10-68328928

E-mail: episodes88@yahoo.com 